\title{
APLIKASI KEBUTUHAN MAKANAN DAN MINERAL PADA ANAK PENDERITA DIARE BERBASIS ANDROID
}

\author{
Nia Saurina \\ Program Studi Teknik Informatika, Fakultas Teknik, Universitas Wijaya Kusuma Surabaya \\ J1. Dukuh Kupang XXV/54, Surabaya 60255, Jawa Timur, Indonesia \\ Email: niasaurina@gmail.com
}

\begin{abstract}
Diarrhea mostly considered as easy case, whereas according to WHO records as many as 6 million children die every year due to diarrhea in developing countries. Based on survey from Sub Directorate of diarrhea and Gastrointestinal Infections (ISP) of the Directorate General of Disease Control and Environmental Health (P2PL) Ministry of Health, Diarrhoea for all ages in 2010 was 411 every 1,000 people, while in 2012 amounted to 214 every 1,000 people, Diarrhea can cause a child suffering from malnutrition and even death. Untill now there is no research specially discuss about children's healthy yet, and made some application for smartphone. Eventhough 50 percent Indonesia citizen has smartphoneand made it for tools for communication. And smartphone has penetration growth in 2016 achieve in 37,1percent. Purpose for this research is made application to give information for parents who have children in aged $4-6$ years old and suffer diarrhea. For this application user can know variety diet and already recommended from expert nor food not good to consume for them. Furthermore, this application also gives information about food and mineral's needed that is required for children to accelerate healing.
\end{abstract}

Keywords: diarrhea, children, mineral and food's needed, Android

\begin{abstract}
ABSTRAK
Diare sering kali dianggap sebagai penyakit sepele, padahal menurut catatan WHO sebanyak 6 juta anak meninggal setiap tahun karena diare yang terjadi di negara berkembang. Berdasarkan hasil survei Sub Direktorat Diare dan Infeksi Saluran Pencernaan (ISP) Direktorat Jenderal Pengendalian Penyakit dan Penyehatan Lingkungan (P2PL) Kementerian Kesehatan RI, Angka Kesakitan Diare untuk semua umur tahun 2010 adalah 411 per 1.000 penduduk, sedangkan pada tahun 2012 sebesar 214 per 1.000 penduduk. Diare dapat menyebabkan anak mengalami malnutrisi bahkan kematian. Sampai saat ini belum adanya penelitian yang khusus membahas mengenai kesehatan terutama bagi anak, dan di implementasikan pada smartphone. Padahal 50 persen pemilik smartphone di Indonesia menjadikan smartphone sebagai peralatan telekomunikasi utama. Bahkan smartphone memiliki total penetrasi pertumbuhan pada tahun 2016 mencapai 37,1 persen. Tujuan penelitian ini adalah membuat aplikasi untuk memberikan informasi kepada orang tua yang memiliki anak usia $4-6$ tahun dan sedang menderita diare. Dari aplikasi ini user dapat mengetahui variasi makanan yang dianjurkan maupun pantangan makanan selama anak diare. Selain itu aplikasi ini juga dapat memberikan informasi kebutuhan makanan dan mineral yang dibutuhkan sesuai dengan jenis diare yang diderita anak.
\end{abstract}

Kata Kunci: diare, anak, kebutuhan makanan dan mineral, Android

\section{PENDAHULUAN}

\section{Latar Belakang}

Diare sering kali dianggap sebagai penyakit sepele, padahal di tingkat global dan nasional fakta menunjukkan sebaliknya. Menurut catatan WHO hingga saat ini penyakit diare masih merupakan masalah kesehatan masyarakat di Indonesia, hal ini dapat dilihat dengan meningkatnya angka kesakitan diare dari tahun ke tahun. Di dunia, sebanyak 6 juta anak meninggal setiap tahun karena diare, sebagian kematian tersebut terjadi di negara berkembang. Di negara berkembang pada tahun 2003 diperkirakan 1,87 juta anak balita meninggal karena diare, 8 dari 10 kematian tersebut pada umur $<2$ tahun. Rata-rata anak usia $<3$ tahun di negara berkembang mengalami diare 3 kali dalam setahun[1]. 
Menurut profil kesehatan Jawa Timur dari Dinas Kesehatan Propinsi Jawa Timur tahun 2012 hingga saat ini penyakit diare masih merupakan masalah kesehatan masyarakat. Berdasarkan hasil survei Sub Direktorat Diare dan Infeksi Saluran Pencernaan (ISP)Direktorat Jenderal Pengendalian Penyakit dan Penyehatan Lingkungan (P2PL)Kementerian Kesehatan RI, Angka Kesakitan Diare untuk semua umur tahun 2010 adalah 411 per 1.000 penduduk, sedangkan pada tahun 2012 sebesar 214 per 1.000 penduduk. Dan berdasarkan hasil Riset Kesehatan Dasar[2[, Diare merupakan penyebab kematian nomor empat $(13,2 \%)$ pada semua umur dalam kelompok penyakit menular dan merupakan penyebab kematian nomor satu pada bayi post neonatal $(31,4 \%)$ dan pada anak balita $(25,2 \%)$. Di Jawa Timur cakupan pelayanan penderita Diare tahun tahun 2011 sebesar 69\%, sedangkan tahun 2012 sebesar 72,43\% (masih di bawah target Nasional 100\%). Dilihat hasil cakupan pelayanan diare di kabupaten/kota tahun 2012, 7 (tujuh) kabupaten/Kota sudah mencapai target 100\%, yakni Kabupaten Bondowoso, Kabupaten Situbondo, Kabupaten Mojokerto, Kabupaten Sampang, Kota Kediri, Kota Pasuruan dan Kota Mojokerto. Sedangkan kabupaten/kota belum bisa mencapai target, karena ketepatan dan kelengkapan laporan dari Puskesmas ke kabupaten/kota sangat rendah[2].

Beberapa penelitian menunjukkan bahwa diare tidak hanya menyebabkan kematian tetapi dapat juga menyebabkan malnutrisi. Diare dapat mengakibatkan berkurangnya nafsu makan dan gangguan pencernaan yang menyebabkan menurunnya absorbsi zat-zat nutrisi dalam tubuh sehingga menimbulkan malnutrisi. Penelitian yang dilakukan oleh Iswari[3]mengatakan bahwa kejadian diare memiliki hubungan yang signifikan dengan status gizi pada anak usia di bawah 2 tahun. Menurut Supariasa[4] gizi merupakan suatu proses useran makanan yang dikonsumsi secara normal melalui proses digesti, absorpsi, transportasi, penyimpanan, metabolisme dan pengeluaran zat-zat yang tidak digunakan untuk mempertahankan kehidupan, pertumbuhan dan fungsi normal dari organ-organ serta menghasilkan energi. Berkaitan dengan status gizi, untuk bertumbuh dan berkembang, anak membutuhkan zat gizi yang esensial mencakup protein, lemak, karbohidrat, mineral, vitamin dan air yang harus dikonsumsi secara seimbang, dengan jumlah yang sesuai kebutuhan pada tahap usianya[5]. Menurut Diah[6], malnutrisi merupakan suatu keadaan kurang energi protein dan defisiensi mikronutrien yang sampai saat ini masih merupakan masalah yang membutuhkan perhatian khusus terutama di negara-negara berkembang.

Sampai saat ini belum adanya penelitian yang khusus membahas mengenai kesehatan terutama bagi anak, dan di implementasikan pada smartphone. Padahal menurut[7] menjelaskan riset Google bersama TNS Australia mendapati, 50 persen pemilik smartphone di Indonesia menjadikan peranti itu sebagai peralatan telekomunikasi utama, termasuk untuk mengakses internet. Dan memiliki total penetrasi pertumbuhan pada tahun 2016 mencapai 37,1 persen. Oleh karena itu penelitian ini bertujuan untuk membuat aplikasi kebutuhan makanan dan mineral pada anak penderita diare yang bertujuan untuk memberikan informasi kebutuhan makanan dan mineral pada anak penderita diare agar orang tua dapat membantu mempercepat penyembuhan dengan caramenjaga asupan makanan anak yang sesuai bagi anak penderita diare.

\section{TINJAUAN PUSTAKA}

\section{Diare}

Diare adalah keadaan frekuensi buang air besar lebih dari 4 kali pada bayi dan lebih dari 3 kali pada anak. Konsistensi feses encer, dapat berwarna hijau atau dapat pula bercampur lendir dan darah atau lendir saja [8].

Diare dapat juga diartikan buang air besar (defekasi) dengan jumlah tinja yang lebih banyak dari biasannya (normalnya $100-200 \mathrm{ml}$ per jam tinja), dengan tinja berbentuk cairan atau setengah padat, dapat pula disertai frekuensi defekasi yang meningkat. Wujud tinja merupakan ukuran yang lebih penting dibanding frekuensi buang air besar. Saat frekuensi buang air besar meningkat, namun wujud tinja lunak dan berisi, maka hal tersebut tidak dikatakan sebagai diare[9].

Berdasarkan Laporan Tahunan Rumah Sakit tahun 2012 (per 31 Mei 2013) yang dilakukan oleh Dinas Kesehatan Provinsi Jawa Timur, kasus penyakit terbanyak pasien rawat jalan di rumah sakit umum di Provinsi Jawa Timur adalah Diare dengan memiliki (3.301 kasus) dan ISPA (2.541 kasus). Sedangkan kasus Demam Dengue memiliki jumlah penderita (1.905 kasus) dan Typoid atau 
Typhus sejumlah (1.826 kasus). Kemudian untuk jumlah penderita anak Fever memiliki (1.673 kasus) dan Karies Gigi sejumlah (822 kasus), selanjutnya penderita Mental \& Behaviour Disorder memiliki (559 kasus). Untuk penderita Diabetes Melitus sudah mulai menyerang anak-anak dengan sejumlah (510 kasus), kemudian untuk demam yang penyebabnya tidak diketahui memiliki (483 kasus), yang dapat dilihat pada Gambar 1.

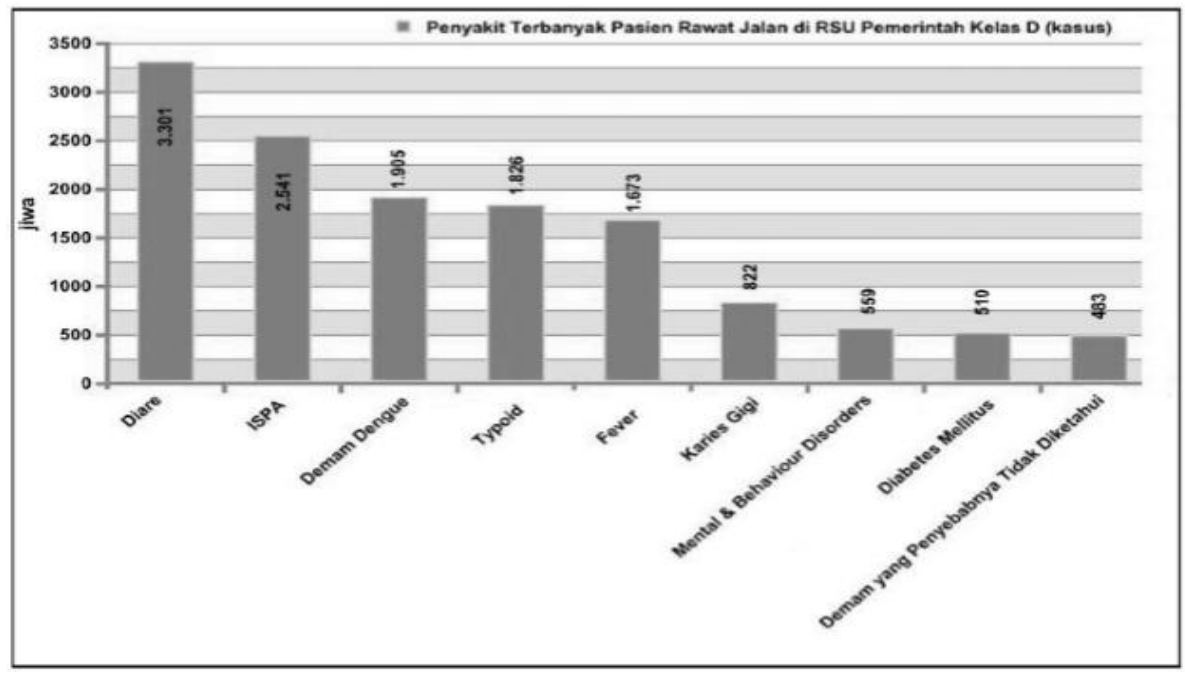

Gambar 1. Penyakit Terbanyak Pasien Rawat Jalan di RSU Provinsi Jawa Timur Tahun 2012 Sumber : Laporan Tahunan Rumah Sakit, Seksi Kesehatan Rujukan dan Khusus, Dinas Kesehatan Provinsi Jawa Timur [2].

\section{Jenis Diare}

Terdapat 3 jenis diare menurut (8), diantaranya:

\section{Diare tanpa dehidrasi}

Penyebab terjadinya diare tanpa dehidrasi adalah virus (Noravirus, Norwaik Agint), bakteri (Escherichia coli, Salmonella, Shigella, Vibrio cholerae, dan Campylobacter), dan Parasit (Candida)

Gejala :

- Keadaan umum : Baik

- Mata : Normal

- Rasa Haus : Normal, Minum Biasa

- Turgor Kulit : Kembali Cepat

\section{Diare dehidrasi ringan/sedang}

Beberapa mikroba penyebab disentri/berdarah akut adalah Salmonella, Campylobacter, Vibrio parahaemolyticus, Shigella, Enteroinvasive E. Coli, dan Entamoeba histolytica.

Gejala :

- Keadaan umum : Gelisah, rewel

- Mata : Cekung

- Rasa Haus : Haus, ingin minum banyak

- Turgor Kulit : Kembali Lambat

\section{Diare dehidrasi berat}

Beberapa mikroba penyebab diare persisten adalah Rotavirus, Aeromonas, Campylobacter, Shigella, dan Cryptosporidium. 
Gejala :

- Keadaan umum : lesu, lunglai, atau tidak sadar

- Mata : Cekung

- Rasa Haus : Tidak bisa minum atau malas minum

- Turgor kulit : kembali sangat lambat (lebih dari 2 detik)

\section{Kebutuhan Makanan untuk Anak Penderita Diare}

Malnutrisi adalah kondisi seseorang yang nutrisinya di bawah rata-rata. Malnutrisi atau gizi buruk ditentukan berdasarkan beberapa pengukuran yaitu pengukuran klinis dan pengukuran antropometrik. Untuk menghindari keadaan malnutri pada anak penderita diare, maka diperlukan asupan makanan dan minuman yang tepat agar proses penyumbuhan anak bisa lebih cepat. Untuk makanan utama anak penderita diare, menurut [10].lebihdisarankan agar anak mengkonsumsi berikut ini :

- Nasi Tim

- Sup

- Bubur

- Kentang

Untuk makanan pendamping bagi anak penderita diare, menurut [10].lebih disarankan untuk mengkonsumsi makanan berikut ini:

- Pisang

- Telur Rebus

- Crackers

- Jelly

- Apel

Sedangkan untuk minuman bagi anak penderita diare, menurut [10].lebih disarankan untuk mengkonsumsi minuman berikut ini:

- Air putih

- Jus Buah

- Air Kelapa

\section{Unified Modelling Language (UML)}

Unified Modelling Language (UML) adalah suatu alat untuk memvisualisasikan dan mendokumentasikan hasil analisa dan desain yang berisi sintak dalam memodelkan sistem secara visual [11]. Juga merupakan satu kumpulan konvensi pemodelan yang digunakan untuk menentukan atau menggambarkan sebuah sistem software yang terkait dengan objek. Tujuan dari useran diagram seperti diungkapan oleh [12], "The purpose of the diagrams is to present multiple views of a system; this set of multiple views is called a model".

\section{Android}

Pada tahun 2005 Google mengakuisisi Android Inc yang pada saat itu dimotori oleh Andy Rubin, Rich Miner, Nick Sears, dan Chris White. Yang kemudian pada tahun itu juga memulai membangun platform Android secara intensif. Kemudian pada tanggal 12 November 2007 Google bersama Open Handset Alliance(OHA) yaitu konsorsium perangkat mobile terbuka, merilis Google Android SDK, setelah mengumumkannya seminggu sebelumnya. Dan sambutanya sangat luar biasa, hampir semua media berita tentang IT dan Programming membritakan tentang dirilisnya Android SDK (Software Development Kit).

Google bersama dengan OHA merilis paket software SDK yang lengkap untuk mengembangkan aplikasi pada perangkat mobile yaitu : Sistem operasi, Middleware dan aplikasi utama untuk perangkat mobile. Sebagai Programmer dan Developer, mereka bisa melakukan segalanya, mulai dari membuat aplikasi pengiriman SMS hanya dengan dua baris kode, hingga mengganti event pada Home Screen perangkat Android. Selain itu, bahkan dengan mudah kita bisa 
membuat dan mengkustomisasi Sistem Operasinya, atau mengganti semua aplikasi default dari Google[13].

\section{METODE}

Penelitian ini memiliki tahapan penelitian seperti Gambar 2.

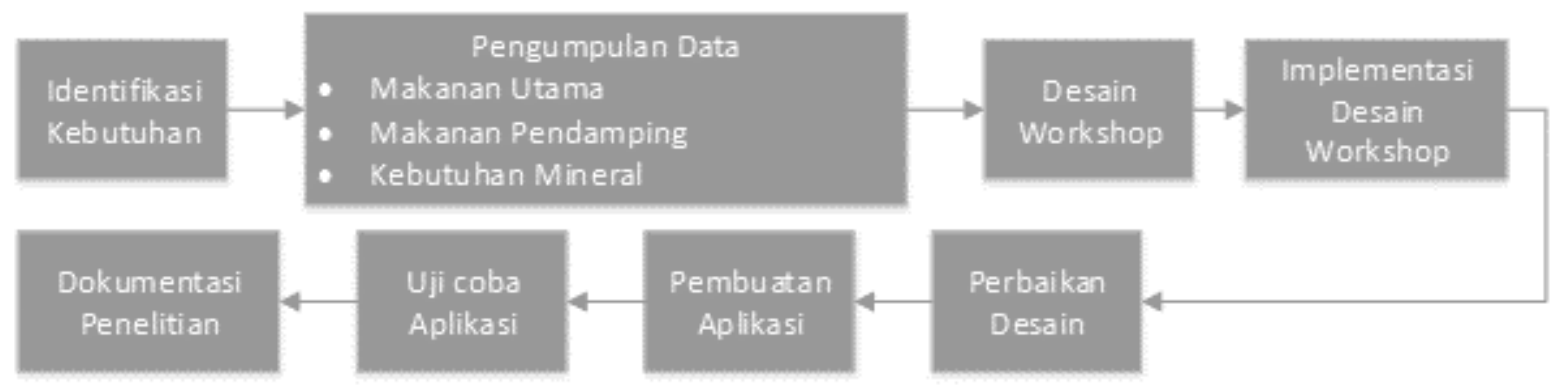

Gambar 2. Alur Penelitian

\section{Identifikasi Kebutuhan}

Pembuatan aplikasi pada penelitian ini menggunakan beberapa teknik dalam pengumpulan data yaitu :

Observasi - Peneliti melakukan penelitian lapangan di 2 (dua) Puskesmas yang dilaksanakan di Dukuh Kupang Surabaya dan Keputih Sukolilo Surabaya, guna mengetahui sampai seberapa jauh penanganan anak penderita diare. Saat ini Pihak Puskesmas memberikan pertolongan pertama dengan memberikan obat untuk menghentikan siklus diare, serta vitamin untuk membantu proses pencernaan. Akan tetapi sampai saat ini pihak orang tua belum mengetahui asupan makanan apa saja yang dibutuhkan oleh anak agar dapat mempercepat proses penyembuhan. Pihak Puskesmas juga memberikan sedikit informasi mengenai ilmu gizi agar anak terhindar malnutrisi selama proses penyembuhan, dikarenakan banyaknya pasien yang perlu mendapatkan pelayanan di hari yang sama.

Wawancara - Melakukan tanya jawab secara langsung pada tim medis kesehatan di Puskesmas sebanyak lima orang sebagai data di lapangan, serta melakukan Tanya jawab pada Ahli Kesehatan yang bekerja di Akademi Gizi di Jalan Bendul Merisi No. 126 Surabaya sebanyak 1 orang dokter anak dan 1 orang Ahli Gizi guna mendapatkan teori mengenai asupan makanan apa saja yang dibutuhkan anak selama proses penyembuhan. Anak sebagai penderita diare membutuhkan nutrisi berupa makanan dan mineral agar tidak terjadi malnutrisi selama anak masih menderita diare. Diare dibagi menjadi 3 jenis yaitu diare tanpa dehidrasi, diare dengan dehidrasi dan diare dengan dehidrasi berat. Untuk kebutuhan Makanan Utama yang dibutuhkan adalah nasi tim, kentang dan bubur. Selain itu diperlukanan makanan pendamping berupa pisang, apel, jelly. Untuk kebutuhan makanan utama dan makanan pendamping, tidak membutuhkan perhatian khusus mengenai jumlah minimal berapa banyak anak seharusnya makan, hal ini dikarenakan keinginan anak untuk makan jelas menurun. Sedangkan kebutuhan mineral diare tanpa dehidrasi adalah $1500 \mathrm{mg} / \mathrm{hari}$ dan kebutuhan mineral diare dengan dehidrasi sebanyak $2200 \mathrm{mg} / \mathrm{hari}$. Untuk diare dengan dehirasi berat, ahli gizi dan dokter anak menyarankan agar peneliti tidak membuat ke dalam bentuk aplikasi, dikarenakan jenis diare ini membutuhkan penanganan khusus.Sedangkan kebutuhan makanan untuk ketiga jenis diare, tidak dibutuhkan jumlah minimal kalori bagi anak. Sehingga Ahli Kesehatan menyarankan agar adanya perbedaan jumlah makanan yang dipilih oleh orang tua di aplikasi, antara diare tanpa dehidrasi dan diare dengan dehidrasi. Jumlah makanan untuk diare dengan dehidrasi haruslah lebih banyak daripada diare tanpa dehidrasi. Aplikasi ini ditujukan pada anak berusia 4-6 tahun dikarenakan kebutuhan makanan dan mineral anak adalah sama, yaitu 1500 $\mathrm{mg} /$ hari untuk diare tanpa dehidrasi dan $2200 \mathrm{mg} / \mathrm{hari}$ untuk diare dengan dehidrasi. 
Riset Pustaka - Mengumpulkan data-data atau sumber yang diperoleh dari berbagai referensi mengenai asupan makanan untuk anak penderita diare serta pembuatan desain antarmuka yang user friendly yang dapat membantu peneliti dalam menyelesaikan pembuatan aplikasi

\section{Desain Aplikasi}

Pada Gambar 3 menjelaskan aplikasi Diet_Diare_Anak, orang tua penderita sebagai aktor dapat memasukkan data berupa nama orang tua, nama anak beserta usia anak.

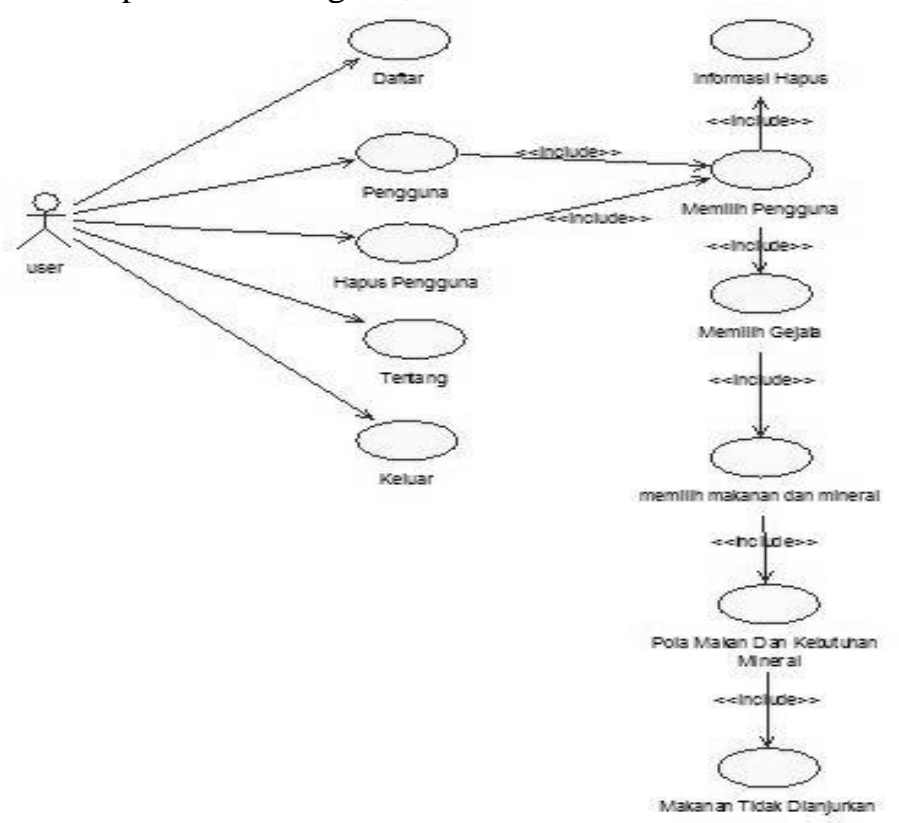

Gambar 3. Use Case Diagram Aplikasi Diet_Diare_Anak

Gambar 3 menjelaskan user dapat menghapus daftar user, dapat membaca informasi mengenai aplikasi yang digunakan pada menu "Tentang". Dan saat user telah memilih salah satu nama yang telah tersimpan di aplikasi, maka user dapat memilih jenis diare sesuai dengan gejala yang ditimbulkan pada anak. User dapat memilih jenis diare dengan dehidrasi atau diare tanpa dehidrasi. Saat user telah memilih salah satu jenis diare, maka user dapat memilih jenis makanan dan minuman yang telah dikonsumsi. Untuk jenis minuman yang dipilih, maka aplikasi menampilkan jumlah banyaknya minuman yang telah dikonsumsi oleh anak. Aplikasi dapat menampilkan keluaran apakah kebutuhan makanan dan mineral yang telah dikonsumsi oleh user telah mencukupi kebutuhan minimal yang disarankan oleh Ahli Kesehatan.

\section{HASIL DAN PEMBAHASAN}

Pada penelitian ini digunakan dua unit device atau smartphone Android untuk uji coba. Masing-masing device memiliki spesifikasi yang berbeda. Tabel 1 menunjukkan spesifikasi dari masing-masing device yang digunakan untuk mengaplikasikan penelitian ini.

Tabel 3. Spesifikasi Smartphone Android

\begin{tabular}{lll}
\hline No & \multicolumn{1}{c}{ Tipe Smartphone } & \multicolumn{1}{c}{ Spesifikasi } \\
\hline \multirow{3}{*}{1} & Sony Ericson Xperia X8 Shakira & - Display 480 x 854 pixels \\
& & - Android OS v4.3 (Jelly Bean) \\
& & - CPU 1 GHz Dual Core \\
\hline \multirow{3}{*}{2} & Samsung & - 480 x 800 (WVGA) pixels \\
& & - Android v4.2.2 (JellyBean) \\
& & - Dual Core Application Processor \\
& & - Cortex A9 1.0GHz Processor \\
\hline
\end{tabular}


Berikut ini adalah tampilan Interface Aplikasi Kebutuhan Makanan dan Mineral pada Anak Penderita Diare, atau diberi nama Aplikasi Diet_Diare_Anak pada Gambar 4.

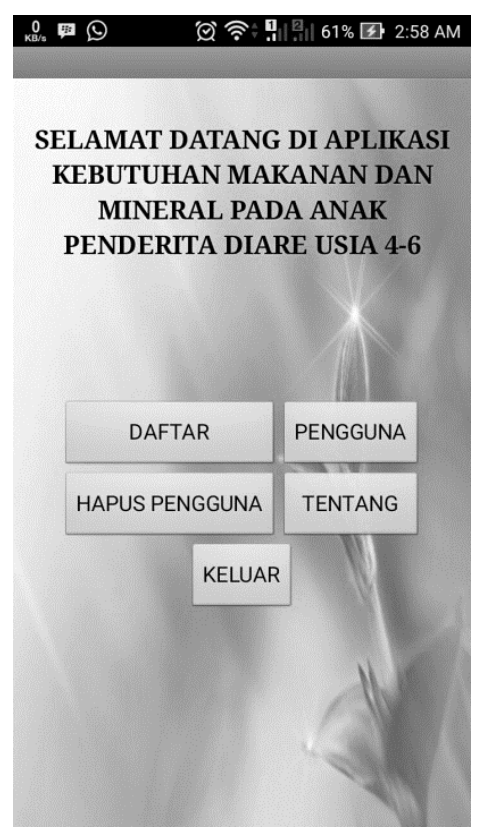

Gambar 4. Halaman Utama Aplikasi

Gambar 5a(kiri) menunjukkan tampilan saat user memasukkan data pribadi anak dengan memasukkan nama anak, jenis kelamin, berat badan dan tinggi badan. Untuk Gambar 5b(tengah) menunjukkan tampilan aplikasi saat user melewatkan isian data yang diminta aplikasi, dan Gambar 5c (kanan) menunjukkan tampilan saat namauser telah berhasil disimpan di aplikasi.

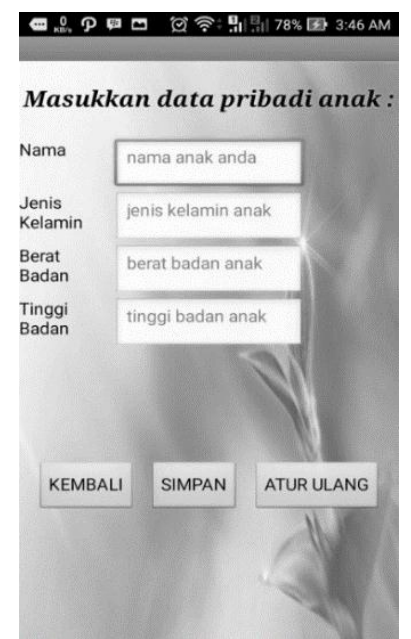

(a)

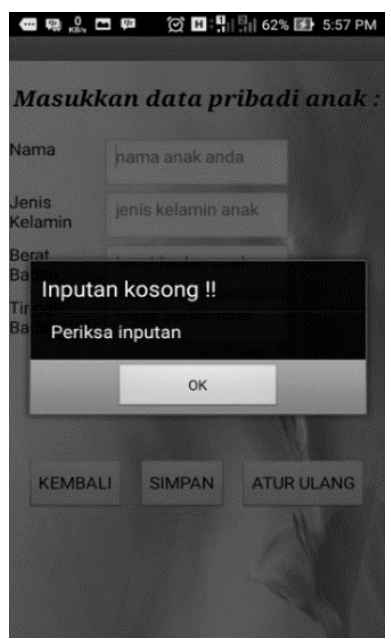

(b)

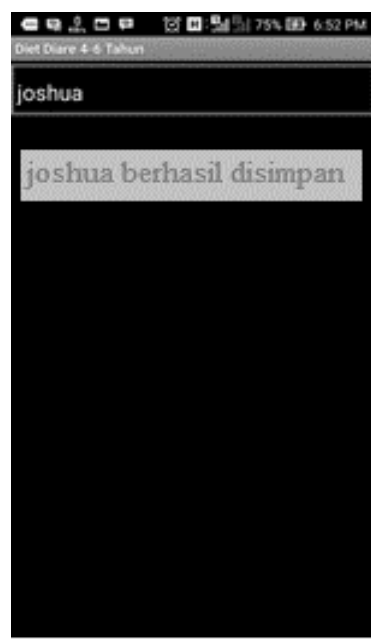

(c)

Gambar 5. Memasukkan Data Anak

Gambar 6 (kiri) menunjukkan daftar variasi kebutuhan makanan dan mineral yang dianjurkan Ahli Kesehatan bagi anak yang sedang menderita diare. Dan Gambar 6 (kanan) menunjukkan daftar makanan yang tidak disarankan bagi anak saat anak menderita diare. 


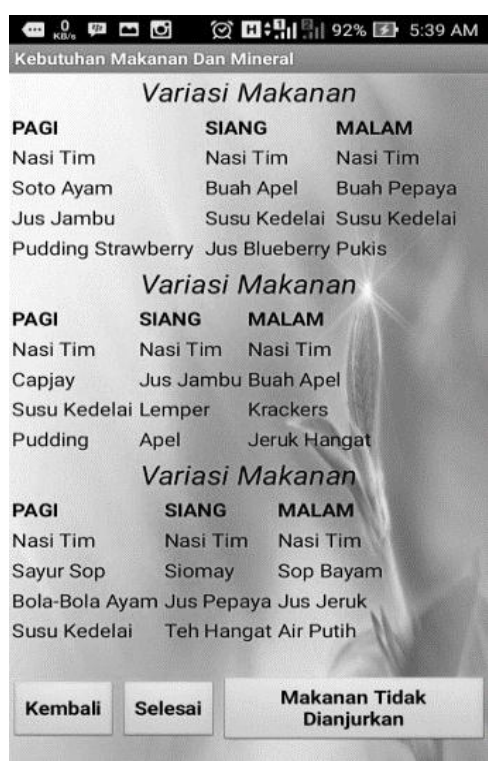

(a)

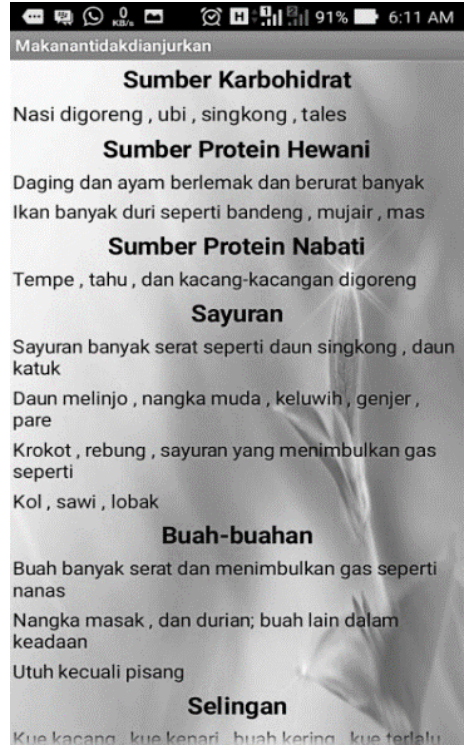

(b)

Gambar 6. Variasi makanan yang dianjurkan (kiri) dan yang tidak dianjurkan (kanan)

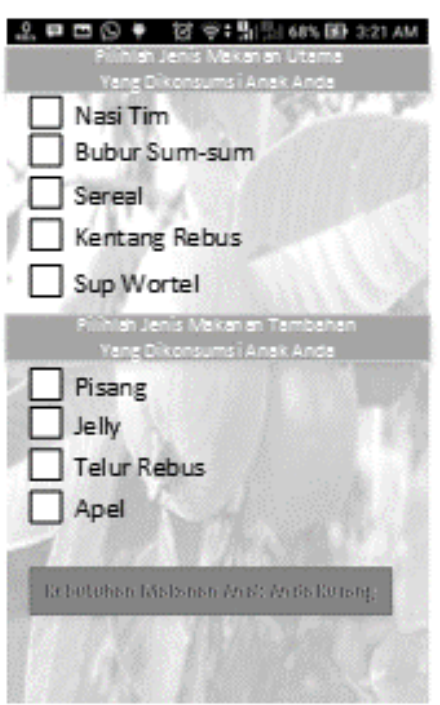

(a)

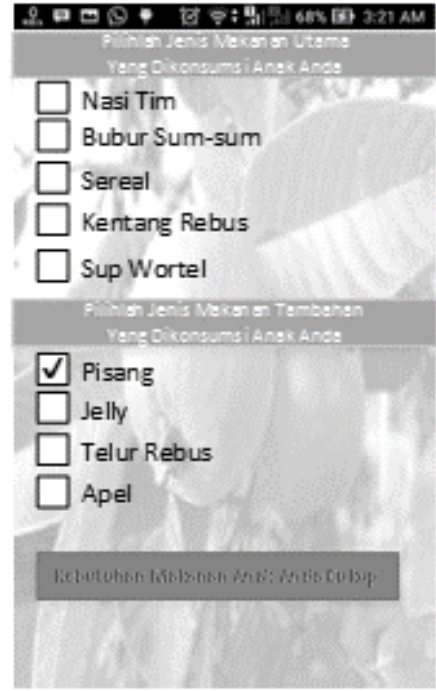

(b)

Gambar 7. Kebutuhan Makanan Diare Tanpa Dehidrasi

Gambar 7 (kiri) menunjukkan tampilan aplikasi di jenis Diare Tanpa Dehidrasi. Saat user belum memilih jenis makanan yang ditampilkan oleh aplikasi, maka pesan yang muncul adalah "Kebutuhan Makanan Anak Anda Kurang". Gambar 7 (kanan) menampilkan saat user memilih 1 jenis makanan, maka aplikasi memberikan pesan "Kebutuhan Makanan Anak Anda Cukup". 


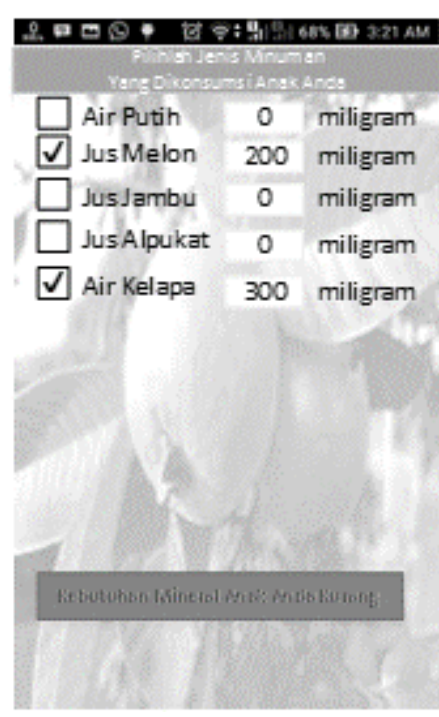

(a)

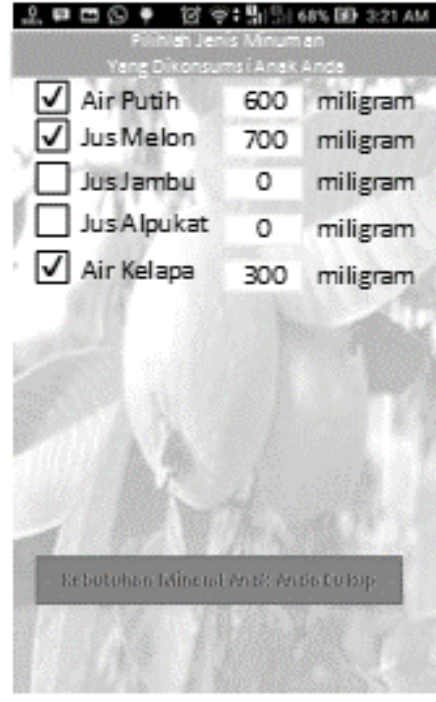

(b)

Gambar 8. Kebutuhan Mineral Diare Tanpa Dehidrasi

Gambar 8 (kiri) menunjukkan tampilan aplikasi di jenis Diare Tanpa Dehidrasi. Saat user belum memilih jenis minuman yang ditampilkan oleh aplikasi, maka pesan yang muncul adalah "Kebutuhan Mineral Anak Anda Kurang". Dan Saat user memilih 1 jenis minuman dan menuliskan jumlah minuman kurang dari $1500 \mathrm{mg}$, maka aplikasi memberikan pesan "Kebutuhan Mineral Anak Anda Kurang". Saar user menuliskan jumlah minuman lebih dari atau sama dengan $1500 \mathrm{mg}$, maka aplikasi memberikan pesan "Kebutuhan Mineral Anak Anda Cukup".

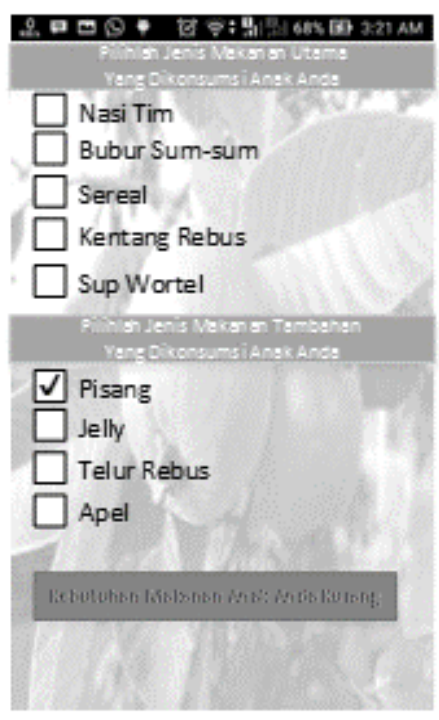

(a)

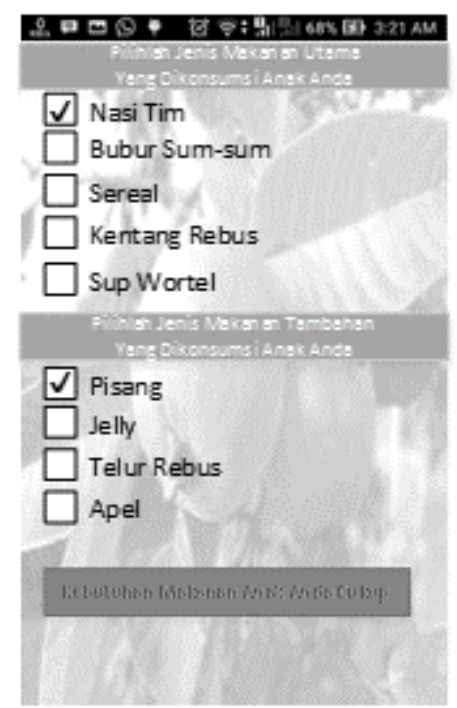

(b)

Gambar 9. Kebutuhan Makanan Diare Dengan Dehidrasi

Gambar 9 (kiri) menunjukkan tampilan aplikasi di jenis Diare Dengan Dehidrasi. Saat user belum memilih jenis makanan yang ditampilkan oleh aplikasi, maka pesan yang muncul adalah "Kebutuhan Makanan Anak Anda Kurang". Dan Saat user memilih 2 jenis makanan, maka aplikasi memberikan pesan "Kebutuhan Makanan Anak Anda Cukup". 


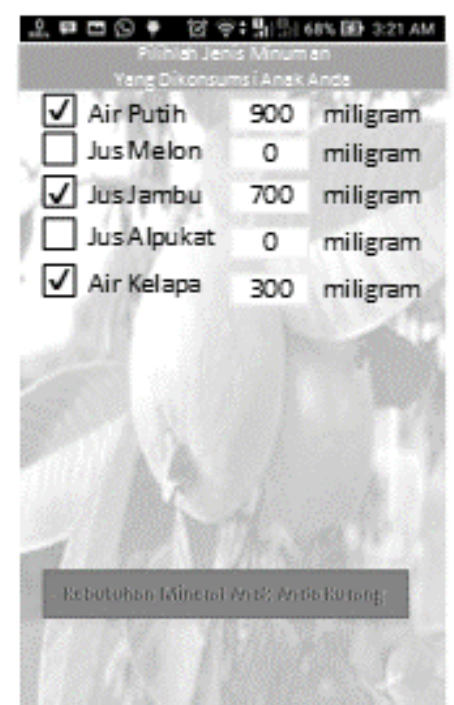

(a)

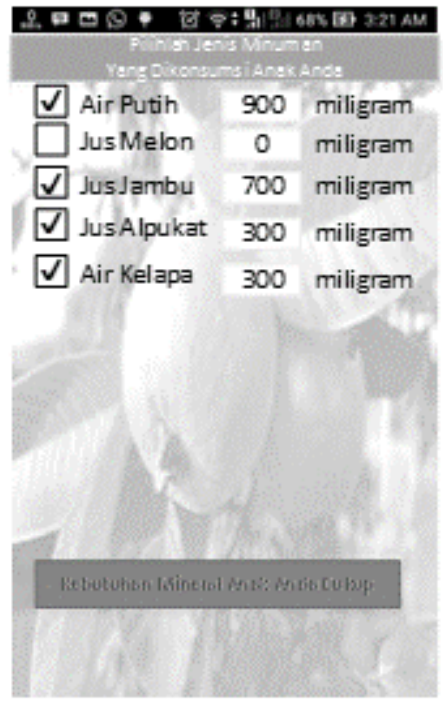

(b)

Gambar 10. Kebutuhan Mineral Diare Dengan Dehidrasi

Gambar 10 (kiri) menunjukkan tampilan aplikasi di jenis Diare Tanpa Dehidrasi. Saat user belum memilih jenis minuman yang ditampilkan oleh aplikasi, maka pesan yang muncul adalah "Kebutuhan Mineral Anak Anda Kurang". Dan Saat user memilih 1 jenis minuman dan menuliskan jumlah minuman kurang dari $2200 \mathrm{mg}$, maka aplikasi memberikan pesan "Kebutuhan Mineral Anak Anda Kurang". Saar user menuliskan jumlah minuman lebih dari atau sama dengan $2200 \mathrm{mg}$, maka aplikasi memberikan pesan "Kebutuhan Mineral Anak Anda Cukup".

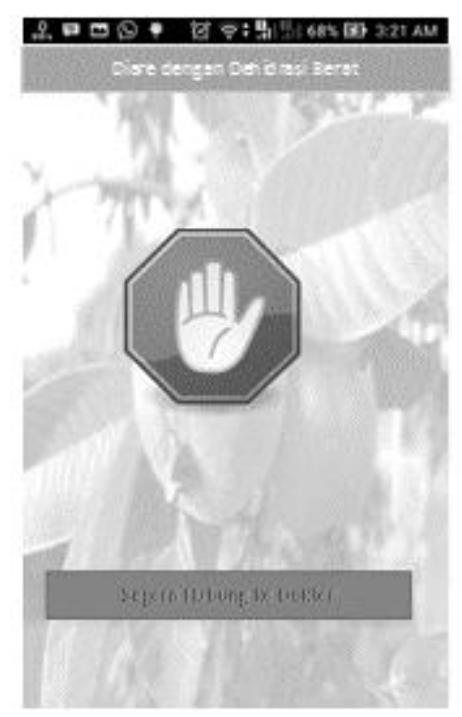

Gambar 11. Diare Dengan Dehidrasi Berat

Gambar 11 menunjukkan tampilan aplikasi di jenis Diare Dengan Dehidrasi Berat. Saat user memilih jenis diare ini, maka aplikasi menampilkan pesan "Segera Hubungi Ke Dokter". Hal ini disarankan oleh Ahli Kesehatan bahwa jenis diare dengan dehidrasi berat, tidak diperbolehkan ditangani oleh aplikasi, karena penderita ini membutuhkan pertolongan secepat mungkin oleh Ahli Kesehatan. 


\section{Pengujian}

Aplikasi diuji cobakan kepada Ahli Kesehatan di Akademi Gizi yang beralamat di Bendul Merisi No. 126 Surabaya sebanyak dua orang, yaitu 1 orang dokter anak dan 1 orang Ahli Gizi. Selain itu aplikasi ini juga diujicobakan pada perawat yang bertugas sebagai tim medis kesehatan dari Puskesmas Dukuh Kupang dan Puskesmas Sukolilo Surabaya sebanyak lima orang dan tiga puluh orang tua yang memiliki anak usia $4-6$ tahun yang sedang menderita diare.

\section{Uji coba (validitas) oleh Ahli Kesehatan}

Kuisioner uji coba untuk Ahli Kesehatan terdiri dari 15 pertanyaan yang mencakup tiga indikator yaitu pertama kesesuaian isi dan tujuan, kesesuaian variasi makanan yang dianjurkan dan pantangan makanan, kesesuaian kebutuhan mineral bagi anak penderita diare untuk diare dengan dehidrasi serta diare tanpa dehidrasi. Skala penilaian dari $1-5$ dengan rentang sangat tidak setuju sampai sangat setuju. Dengan interpretasi skor menggunakan skala likert (14) yaitu 0\% - 100\% dengan rentang dari sangat kurang baik hingga sangat baik.

Tabel 2. Hasil Kuisioner Uji Coba Ahli Kesehatan

\begin{tabular}{llcc}
\hline No & Indikator & Persentase rata-rata & Keterangan \\
\hline 1 & Kesesuaian isi dan tujuan & $83 \%$ & Sangat Setuju \\
\hline 2 & $\begin{array}{l}\text { Kesesuaian variasi makanan yang } \\
\text { dianjurkan dan pantangan makanan }\end{array}$ & $84 \%$ & Setuju \\
\hline 3 & $\begin{array}{l}\text { Kesesuaian kebutuhan mineral bagi anak } \\
\text { penderita diare untuk diare dengan } \\
\text { dehidrasi dan diare tanpa dehidrasi }\end{array}$ & $88 \%$ & Sangat Setuju \\
\hline$\quad$ Rata-rata keseluruhan & $\mathbf{8 5 \%}$ & Sangat Baik \\
\hline
\end{tabular}

Dari tabel 2 terlihat bahwa indikator kesesuaian isi dan tujuan sebesar 83\%, indikator kesesuaian variasi makanan yang dianjurkan dan pantangan makanan yang dapat ditampilkan oleh aplikasi sebesar $84 \%$, dan kesesuaian kebutuhan mineral bagi anak penderita diare untuk diare dengan dehidrasi dan diare tanpa dehidrasi sebesar $88 \%$ dengan rata-rata keseluruhan indikator yaitu 85\%. Dengan nilai persentase sebesar 85\% maka aplikasi Diet_Diare_Anak yang telah dibuat dapat dikategorikan sebagai alat bantu yang sangat baik dan bisa diterapkan atau digunakan oleh orang tua dalam mendapatkan informasi kebutuhan makanan dan mineral bagi anak penderita diare.

\section{Uji coba (validitas) oleh Tim Medis Kesehatan.}

Langkah pertama dalam ujicoba ini yaitu Kepala Puskesmas maupun perawat diberikan kesempatan untuk mencoba aplikasi yang telah dibuat kemudian diberikan kuisioner untuk diisi. Kuisioner terdiri dari 21 pertanyaan yang memuat tiga indikator yaitu kesesuaian isi dan tujuan, kesesuaian kebutuhan makanan dan mineral bagi anak penderita diare, serta teknis dan desain. Adapun hasil dari kusioner tersebut disajikan pada Tabel 3.

Tabel 3. Hasil kuisioner uji coba pada Tim Medis Kesehatan di dua Puskesmas

\begin{tabular}{llcc}
\hline No & Indikator & Persentase rata-rata & Keterangan \\
\hline 1 & Kesesuaian isi dan tujuan & $81 \%$ & Sangat Setuju \\
\hline 2 & $\begin{array}{l}\text { Kesesuaian kebutuhan makanan dan } \\
\text { mineral bagi anak penderita diare }\end{array}$ & $87 \%$ & Sangat Setuju \\
\hline 3 & Teknis (desain) & $92 \%$ & Sangat Setuju \\
\hline$\quad$ Rata-rata keseluruhan & $\mathbf{8 6 \%}$ & Sangat Baik \\
\hline
\end{tabular}

Dari hasil uji coba terhadap tim medis kesehatan menunjukkan hasil untuk kesesuain isi dan tujuan sebesar $81 \%$, kesesuaian kebutuhan makanan dan mineral bagi anak penderita diare sebesar 
$87 \%$ dan kualitas teknis sebesar $92 \%$, serta total rata-rata dari keseluruhan indikator yaitu $86 \%$, hal ini menujukkan bahwa aplikasi Diet_DIare_Anak memiliki nilai yang sangat baik.

\section{Uji coba (validitas) oleh Orang Tua}

Uji coba dilakukan pada orang tua yang memiliki permasalahan tumbuh kembang anak yang berbeda-beda dengan melibatkan 30 responden. Orang tua diminta untuk mengisi kuisioner yang berisi tanggapan terhadap media aplikasi yang dibuat. Hasil dari kuisioner yang diberikan kepada orang tua disajikan pada Tabel 4.

Tabel 4. Hasil kuisioner uji coba pada Orang Tua

\begin{tabular}{llcc}
\hline No & Indikator & Persentase rata-rata & Keterangan \\
\hline 1 & Tampilan Media & $81 \%$ & Sangat Setuju \\
\hline 2 & Pengoperasian Media & $84 \%$ & Setuju \\
\hline 3 & Penyajian Materi & $78 \%$ & Sangat Setuju \\
\hline 4 & Useran Bahasa & $88 \%$ & Sangat Setuju \\
\hline & Rata-rata keseluruhan & $\mathbf{8 2 \%}$ & Sangat Baik \\
\hline
\end{tabular}

Dari hasil uji coba terhadap orang tua menunjukkan hasil untuk tampilan media sebesar $81 \%$, pengoperasian media sebesar $84 \%$, penyajian materi sebesar $78 \%$ dan useran bahasa sebesar $88 \%$, sehingga total rata-rata dari keseluruhan indikator yaitu $82 \%$, hal ini menujukkan bahwa aplikasi Diet_Diare_Anak memiliki nilai yang sangat baik.

\section{KESIMPULAN}

Berdasarkan hasil pembahasan dan ujicoba yang dilakukan, maka dapat diambil kesimpulan adalah sebagai berikut:

1. Aplikasi Diet_Diare_Anak dapat memberikan informasi yang benar sesuai dengan saran Ahli Kesehatan mengenai makanan yang dianjurkan dan pantangan makanan bagi anak usia $4-6$ tahun yang sedang menderita diare

2. Aplikasi ini dapat memberikan informasi jumlah makanan yang dimasukkan oleh user. Hal ini terbukti pada saat user tidak memilih makanan pada aplikasi, maka aplikasi menampilkan pesan bahwa "Kebutuhan Makanan Anak Anda Kurang", dan saat user memilih satu makanan yang ditampilkan, maka aplikasi dapat menampilkan pesan "Kebutuhan Makanan Anak Anda Cukup" untuk jenis diare tanpa dehidrasi. Sedangkan untuk jenis diare dengan dehidrasi, maka user memilih minimal dua jenis makanan yang ditampilkan aplikasi. Saatuser memilih kurang dari dua jenis makanan, maka aplikasi dapat menampilkan pesan "Kebutuhan Makanan Anak Anda Kurang", dan saat user memilih dua jenis makanan, maka aplikasi dapat menampilkan pesan "Kebutuhan Makanan Anak Anda Cukup".

3. Aplikasi dapat memberikan informasijumlah kebutuhan mineral bagi anak penderita diare tanpa dehidrasi. Saat user memasukkan kurang dari $1500 \mathrm{mg}$, maka aplikasi menampilkan pesan bahwa "Kebutuhan Mineral Anak Anda Kurang". Dan saat user memasukkan $1500 \mathrm{mg}$ maupun lebih dari $1500 \mathrm{mg}$, maka aplikasi menampilkan pesan bahwa "Kebutuhan Mineral Anak Anda Cukup". Dan untuk jenis diare dengan dehidrasi, saat user memasukkan kurang dari $2200 \mathrm{mg}$, maka aplikasi menampilkan pesan bahwa "Kebutuhan Mineral Anak Anda Kurang". Dan saat user memasukkan $2200 \mathrm{mg}$ maupun lebih dari $2200 \mathrm{mg}$, maka aplikasi menampilkan pesan bahwa "Kebutuhan Mineral Anak Anda Cukup".

4. Terdapat 3 sasaran uji coba aplikasi yang telah dilakukan yaitu Ahli Kesehatan menghasilkan persentase sebesar $85 \%$, kemudian uji coba aplikasi oleh tim medis kesehatan menghasilkan persentase sebesar $86 \%$, serta uji coba aplikasi kepada orang tua anak dengan menghasilkan persentase sebesar $82 \%$, dimana ketiga kelompok tersebut menyatakan bahwa aplikasi dapat dikategorikan sebagai alat bantu yang sangat baik dan bisa digunakan orang tua untuk memberikan informasi mengenai kebutuhan makanan dan mineral bagi anak penderita diare. 


\section{DAFTAR PUSTAKA}

[1] WHO. 2013. Diarrhea: Common Illness, Global Killer. U.S. World Health Organization.

[2] Dinkes. 2012. Profil Kesehatan Jawa Timur Tahun 2012. Dinas Kesehatan Propinsi Jawa Timur.

[3] Iswari.Y. Analisis Faktor-Faktor Resiko Kejadian Diare Pada Anak Usia Dibawah 2 Tahun Di RSUD kota Jakarta.Jurnal Kesehatan Masyarakat, Universitas Ahmad Dahlan. Volume 2: 23-32. 2011.

[4] Supariasa. 2011. Penilaian Status Gizi. Jakarta: Penerbit Kedokteran EGC

[5] Supartini, Y. Hubungan Diare Dengan Kejadian Malnutrisi Pada Balita Di Irina E Bawah RSUP Prof. Dr. R. D. Kandou Manado. Buku Ajar Konsep Dasar Keperawatan Anak. Jakarta: Penerbit Kedokteran EGC. 2004

[6] Diah. 2011. Hubungan Diare Dengan Kejadian Malnutrisi Pada Balita Di Irina E Bawah RSUP. Kandou Manado.

[7] Brata, Komang Candra; Soebroto, Arief Andy; Arwani, Issa. Rancang Bangun Aplikasi Jejaring Sosial Kampus Berbasis GPS Pada Smartphone Android. Journal Basic Science And Technology, 1(2),20-26,2012 ISSN : 2089-8185: 37 - 43. 2012.

[8] Ngastiyah. Karya Tulis Ilmiah Asuhan Keperawatan Pada An. M Dengan Diare Diruang Flamboyan RSI Muhammadiyah Pekajangan Pekalongan. Jurnal Keperawatan. Universitas Muhammadiyah Pekajangan. VolumeI: 22 -29. 2005

[9] Mansjoer.A. Karya Tulis Ilmiah Asuhan Keperawatan Pada An. M Dengan Diare Diruang Flamboyan RSI Muhammadiyah Pekajangan Pekalongan. Jurnal Asuhan Keperawatan. Universitas Muhammadiyah Pekajangan. Volume I: 27 - 34. 2000.

[10] Mega Pricilia Kurnia Sampul, A. L. Hubungan Diare Dengan Kejadian Malnutrisi Pada Balita Di Irina E Bawah RSUP Prof. Dr. R. D. Kandou. ejournal Keperawatan (e-Kp) Volume 3. Nomor 1. Februari 2015.

[11] Ivar Jacobson, M. C. 1992. Object Oriented Software Engineering: A Use Case Driven Approach. Addison Wesley.

[12] James Rumbaugh, M. B. 1991. Object Oriented Modelling and Design. Prentice Hall.

[13] Safaat H, Nazruddin. 2012. Pemrograman Aplikasi Mobile Smartphone dan Tablet PC Berbasis Android (Edisi Revisi). Bandung: Penerbit Informatika

[14] Tustiyana Windiyani. Instrumen Untuk Menjaring Data Interval. Nominal, Ordinal Dan Data Tentang Kondisi, Keadaan, Hal Tertentu Dan Data Untuk Menjaring Variabel Kepribadian. Jurnal Pendidikan Dasar Vol. 3, No. 5 - Desember: 35 - 42. 2012 
- Halaman ini sengaja dikosongkan - 